\title{
Pica, constipation and cardiorespiratory arrest
}

\author{
Inês Mourato Nunes, ${ }^{1}$ Ana Isabel Pedroso, ${ }^{2}$ Manuel Irimia, ${ }^{3}$ Armindo Ramos ${ }^{4}$
}

'Department of Internal Medicine, Hospital de Egas Moniz, Lisboa, Portugal ${ }^{2}$ Department of Medicine, Hospital de Cascais Dr José de Almeida, Alcabideche, Cascais, Portugal

${ }^{3}$ Intensive Care Unit, Hospital de Cascais Dr. José de Almeida, Alcabideche, Cascais, Lisboa, Portugal

${ }^{4}$ Intensive Care Unit Director, Hospital de Cascais Dr. José de Almeida, Alcabideche, Cascais, Lisboa, Portugal

\section{Correspondence to} Dr Inês Mourato Nunes, inesmouratonunes@gmail.com

Accepted 8 June 2017

\section{DESCRIPTION}

Pica is an eating disorder typically defined as the persistent ingestion of non-nutritive substances, for at least 1 month, at an age of which this behaviour is inappropriate. It may be benign or may have life-threatening consequences. ${ }^{12}$ The clinical presentation is highly variable and is associated with the specific nature of the resulting medical conditions and the ingested substances. The signs and symptoms can be from toxic, infectious, dental or gastrointestinal conditions. ${ }^{3}$

The authors present a clinical case of a 61-year-old man with clinical history of cognitive impairment and pica, admitted in an intensive care unit after cardiorespiratory arrest. The initial hospital admission was for constipation and abdominal pain. Abdominal and pelvic CT scan revealed 'significant colonic dilatation with a sigmoid size of $14.5 \mathrm{~cm}$, with evidence of abundant intraluminal faecal content at this level-aspects suggestive of translating obstructive process by faecaloma, visualising bone and metallic contents inside'. A rectal touch was performed with extraction of abundant faeces and foreign bodies (bones and screws). After abundant excretion, he had bradycardia with haemodynamic instability

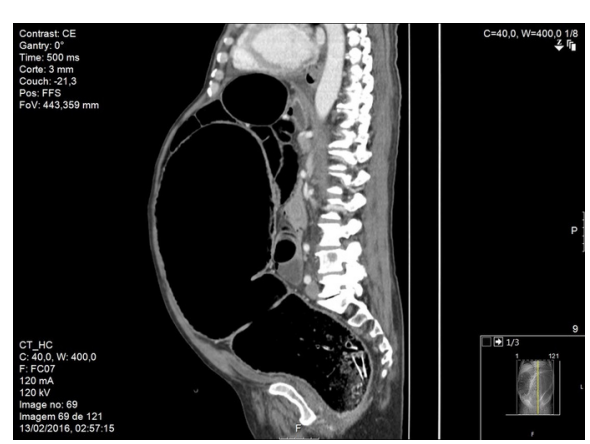

Figure 1 CT scan—sagittal plane—-marked colic dilatation with rectum foreign bodies.

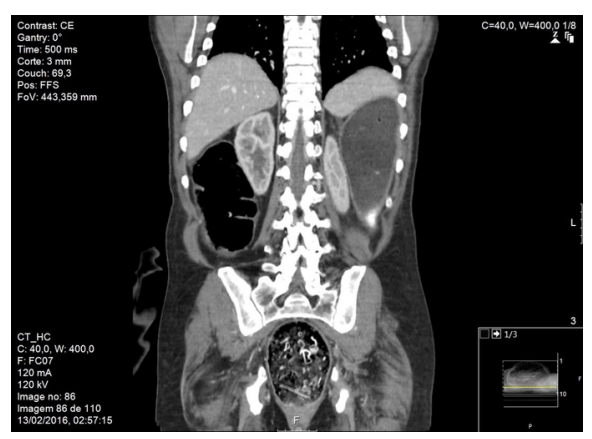

Figure 2 CT scan—coronal plane—-dilated rectum with foreign bodies inside.

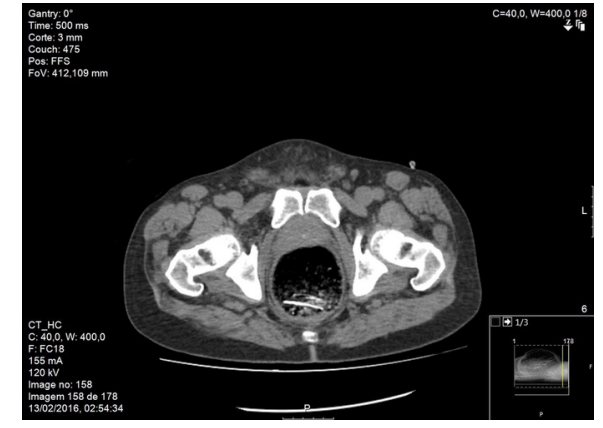

Figure 3 CT scan-transversal plane-dilated rectum with bones/screws inside.

\section{Learning points}

- Pica is a dangerous form of self-injuries behaviour that occurs in people with developmental disabilities who are institutionalised.

- Remember that gastrointestinal complications associated with pica range from mild (eg, constipation) to life-threatening conditions (eg, perforations or ulcerations).

and altered state of consciousness, culminating in cardiorespiratory arrest in asystolia and subsequently ventricular fibrillation with recovery after advanced life support. The patient was submitted to colonic transversostomy with improvement of the condition.

These are striking images, the consequence of an often benign disorder that may have the most tragic outcome (figures 1-3).

Contributors IMN: conception and design, acquisition of data; drafting the article. AIP: acquisition of data. MI, AR: revising it critically for important intellectual content; final approval of the version published.

Competing interests None declared.

Patient consent Obtained.

Provenance and peer review Not commissioned; externally peer reviewed.

(C) BMJ Publishing Group Ltd (unless otherwise stated in the text of the article) 2017. All rights reserved. No commercial use is permitted unless otherwise expressly granted.

\section{REFERENCES}

1 Forman SF. Eating disorders: overview of epidemiology, clinical features, and diagnosis. literature review current through. 2017 www.uptodate.com.

2 Ellis CR. Pica: pratic essentials, background, etiology, prognosis, clinical presentation, workup and treatment. 2017 www.medscape. com.

3 Williams DE, McAdam D. Assessment, behavioral treatment, and prevention of pica: Clinical guidelines and recommendations for practitioners. Res Dev Disabil 2012;33:2050-7. 
Copyright 2017 BMJ Publishing Group. All rights reserved. For permission to reuse any of this content visit http://group.bmj.com/group/rights-licensing/permissions.

BMJ Case Report Fellows may re-use this article for personal use and teaching without any further permission.

Become a Fellow of BMJ Case Reports today and you can:

- Submit as many cases as you like

- Enjoy fast sympathetic peer review and rapid publication of accepted articles

Access all the published articles

- Re-use any of the published material for personal use and teaching without further permission

For information on Institutional Fellowships contact consortiasales@bmjgroup.com

Visit casereports.bmj.com for more articles like this and to become a Fellow 